of $9 \%$. These effects may be increased by dehydration, which is itself produced by the diuretic effect of the contrast medium. It is suggested that these 3 infants had a mild form of NEC after damage to the colonic mucosa by the hyperosmolar effects of contrast medium. Alternatively, arterial vasospasm, previously described during renal angiography, ${ }^{8}$ might have been responsible.

The use of recently developed nonionic contrast media such as metrizamide, which have one-third the osmolality of conventional media, may help to avoid this complication in small infants undergoing cardiac angiography.

\section{References}

1 Leonidas J C, Hall R T. Neonatal pneumatosis coli: a mild form of necrotizing enterocolitis. J Pediatr 1976; 89: 456-9.

2 Bunton G L, Durbin G M, McIntosh N, et al. Necrotising enterocolitis. Arch Dis Child 1977; 52: 772-7.
3 Frantz I D, III, L'Heureux P, Engel R R, Hunt C E. Necrotizing enterocolitis. J Pediatr 1975; 86: 259-63.

4 Hakanson D O, Oh W. Necrotizing enterocolitis and hyperviscosity in the newborn infant. $J$ Pediatr 1977; 90: 458-61.

5 Howard F M, Flynn D M, Bradley J M, Noone P, Szawatkowski M. Outbreak of necrotising enterocolitis caused by Clostridium butyricum. Lancet 1977; 2: 1099102.

- Touloukian R J, Kadar A, Spencer R P. The gastrointestinal complications of neonatal umbilical venous exchange transfusion-a clinical and experimental study. Pediatrics 1973; 51: 36-43.

7 Standen J R, Nogrady M B, Dunbar J S, Goldbloom R B. Osmotic effects of methylglucamine diatrizoate (Renografin 60) in intravenous urography in infants. $A J R$ 1965; 93: 473-9.

8 Spriggs D W, Brantley R E. Recognition of renal arterial spasm during renal angiography. Radiology 1978; 127: 363-6.

Correspondence to Dr R W I Cooke, Department of Child Health, Alder Hey Children's Hospital, Eaton Road, Liverpool L12 2AP.

\title{
Accidental administration of Syntometrine in adult dosage to the newborn
}

\author{
M F WHITFIELD AND S A W SALFIELD \\ Subregional Neonatal Intensive Care Unit, Jessop Hospital for Women, Sheffield, and \\ Department of Paediatrics, University of Sheffield
}

SUMMARY The clinical course is described of an infant who accidentally received an adult dose of Syntometrine (synthetic oxytocin + ergometrine) at delivery. The infant soon became ill with convulsions and ventilatory failure, and later with water intoxication. Similar reported cases are reviewed and recommendations are given for the management of future cases.

Even in the best run labour units accidents can happen. This paper describes the effects on an infant of the accidental administration of an adult dose of Syntometrine, $1 \mathrm{ml}$ of which contains Syntocinon (synthetic oxytocin) 5 units, and ergometrine maleate $0.5 \mathrm{mg}$.

\section{Case report}

The infant, a girl, the first child of a 23-year-old mother, was born by spontaneous vertex delivery at term weighing $3 \cdot 2 \mathrm{~kg}$. The pregnancy and labour had been uncomplicated; there was no evidence of fetal distress, and the baby was in good condition at birth.
During the 6 hours in labour the mother had received only 3.75 units Syntocinon in 2 litres $5 \%$ glucose IV.

The baby was accidentally given $1 \mathrm{ml}$ Syntometrine IM immediately after delivery. 15 minutes later she was centrally cyanosed and had grunting respiration. One hour after the injection a fractional inspired oxygen $\left(\mathrm{F}_{1} \mathrm{O}_{2}\right)$ of 0.5 was needed to abolish cyanosis and she had become hypopnoeic, 'mucousy', and had generalised hypertonus tending to opisthotonus. This state appeared to be due to convulsions, and phenobarbitone $7.5 \mathrm{mg}$ given 8-hourly IM was started. An umbilical arterial catheter was passed and at age $2 \frac{1}{2}$ hours the blood-gases in $\mathrm{F}_{1} \mathrm{O}_{2} \mathrm{O} .5$ were $\mathrm{pH}$ $7.06, \mathrm{PaCO}_{2} 88.7 \mathrm{mmHg}(11.8 \mathrm{kPa}), \mathrm{PaO}_{2} 38$ $\mathrm{mmHg}(5 \mathrm{kPa})$, base excess $8.4 \mathrm{mmol} / 1.90 \mathrm{~min}$ later the blood-gases had deteriorated to $\mathrm{pH} \mathrm{6.9}, \mathrm{PaCO}_{2}$ $102 \mathrm{mmHg}(13.6 \mathrm{kPa})$, base excess $11 \mathrm{mmol} / \mathrm{l}$. Intermittent positive pressure ventilation was given at $35 / \mathrm{min}$, with $\mathrm{F}_{\mathrm{IO}} \mathrm{O}_{2} 0 \cdot 8$, inspiratory/expiratory ratio $1: 1$, peak pressure $25 \mathrm{cmH}_{2} \mathrm{O}$, and $5 \mathrm{~cm}$ positive end expiratory pressure. By 14 hours $\mathrm{F}_{1} \mathrm{O}_{2}$ could be reduced to $0 \cdot 3$, and she was weaned from the ventilator at 42 hours.

Between 4 and 42 hours of age the baby had 
generalised convulsions and received diazepam $5 \mathrm{mg}$, phenobarbitone $45 \mathrm{mg}$, and paraldehyde $0.5 \mathrm{ml}$. At the onset of convulsions the plasma calcium, magnesium, urea, and electrolytes and the blood glucose levels were all normal.

No urine was passed until 19 hours and by 48 hours her weight was $180 \mathrm{~g}$ above birthweight, with gross oedema, and serum $\mathrm{Na} 102 \mathrm{mmol} / \mathrm{l}$. Fluid intake (10\% glucose) in the first 24 hours was $60 \mathrm{ml} / \mathrm{kg}$ and in the second 24 hours $76 \mathrm{ml} / \mathrm{kg}$. The course of plasma electrolyte and urine osmolality measurements is summarised in the Table.

Table Changes in plasma electrolytes and urinary osmolality during the first 4 days of life

\begin{tabular}{llll}
\hline Age (days) & $\begin{array}{l}\text { Plasma sodium } \\
(\text { mmol/l) })\end{array}$ & $\begin{array}{l}\text { Plasma chloride } \\
(\text { mmol/l) }\end{array}$ & $\begin{array}{l}\text { Urine osmolality } \\
(\text { mmol/kg })\end{array}$ \\
\hline 1 & 129 & 94 & 358 \\
2 & 102 & 75 & 423 \\
& & & 213 \\
& & & 147 \\
4 & 127 & 87 & 111 \\
\hline
\end{tabular}

Other investigations included normal platelet, differential and neutrophil counts, and a normal coagulation screen on two occasions in the first 4 days of life. Dextrostix ranged between 45 and 90 $\mathrm{mg} / 100 \mathrm{ml}$ in the first 36 hours ( 5 measurements).

Breast feeding was established by the 5 th day and the baby discharged at 7 days of age. Subsequent follow-up, so far to one year, has shown a developmentally normal infant performing better than average for age, with normal neurological examination, hearing, and eyesight.

\section{Discussion}

Two previous cases of accidential administration of Syntometrine have been recorded ${ }^{1-2}$ both receiving $1 \mathrm{ml}$. The $2 \cdot 84-\mathrm{kg}$ infant described by Kenna ${ }^{1}$ developed respiratory depression within half an hour and required mechanical ventilation at 2 hours for the next 50 hours. Convulsions began at 3 hours and these were treated with phenobarbitone and diazepam. At 18 months of age the baby was neurologically normal. This case is similar to ours.

Brereton-Stiles ${ }^{2}$ described an infant of $3.5 \mathrm{~kg}$ who developed 'myoclonic seizures' and respiratory depression within 2 hours of the injection. The myoclonic seizures were treated with chlorpromazine and the baby's respiratory state remained satisfactory in $\mathrm{F}_{1} \mathrm{O}_{2} \mathbf{0 . 3}$ until 6 hours of age when a brief period of manual ventilation was required. She was much improved by 24 hours of age and normal at 4 days. No follow-up is reported.
Two further cases have been notified to Sandoz (the manufacturers of the drug) from Finland who exhibited skin flushing and cardiac arrhythmias; both recovered. In one other case (known to the Poisons Information Centre at Guy's Hospital, London) the baby developed respiratory arrest and required ventilating for 12 hours. He was also hypertonic and had peripheral vasoconstriction of one foot but made a full recovery.

Syntometrine is widely used in the management of the third stage of labour to reduce postpartum haemorrhage, ${ }^{3}$ oxytocin producing a rapid but unsustained uterine contraction, while ergometrine produces a prolonged contraction of slower onset. Effects of overdosage with ergometrine are vascular smooth muscle spasm, hypertension and depression of the central nervous system particularly of the respiratory centre, and convulsions. Syntocinon can produce hypotension and in overdose, even the synthetic form of oxytocin has an antidiuretic effect. There have been reports of hyponatraemia and convulsions in the newborn baby due to apparent inability of the mother to excrete a fluid load while receiving an oxytocin drip during labour. ${ }^{4-5}$

Our infant received about 20 times the adult dosage of Syntometrine in terms of body weight. The clinical problems were convulsions and respiratory depression caused by ergometrine, and dilutional hyponatraemia due to the antidiuretic effect of a very large dose of oxytocin despite a conservative fluid intake. The mother received only a small dose of oxytocin during labour and it seems unlikely that this was a contributory factor. Artificial ventilation with positive end expiratory pressure might also have contributed to an inappropriate antidiuretic effect, but the severity in this case far exceeded our previous experience with ventilation alone. Cerebral oedema might also have contributed to the difficulty in controlling her convulsions.

The initial requirement of high $\mathrm{F}_{\mathrm{I}} \mathrm{O}_{2}$ and ventilation pressures, and the long inspiratory time suggest pulmonary vascular spasm which relaxed after 14 hours. Provided blood pressure can be adequately monitored, pulmonary arterial dilators-such as tolazoline $(1-2 \mathrm{mg} / \mathrm{kg} \mathrm{IV})^{6}$ or nitroprusside $(2 \mu \mathrm{g} / \mathrm{kg}$ per $\mathrm{min})^{7}$-might be of benefit in future cases where adequate oxygenation is a problem in the first few hours, despite ventilation. Muscular hypertonicity and convulsions also contribute to the difficulties in respiratory management.

Because of the acute nature of the problem, an account of accidental Syntometrine poisoning should be given in all neonatology textbooks. At present it is difficult to get information quickly about the likely course of events. 
We thank the Poisons Information Centre at Guy's Hospital London, and Sandoz Products Limited, for their swift co-operation in the management of this case, and Dr J A Black for permission to report it.

\section{References}

1 Kenna A P. Accidental adminstration of Syntometrine to a newborn infant. BrJ Obstet Gynaecol 1972; 79:764-6.

2 Brereton-Stiles G C, Winship W S, Goodwin N M, Roos R F. Letter: Accidental administration of Syntometrine to a neonate. $S$ Afr Med J 1972; 46: 2052.

3 Embrey M P, Barber D T C, Scudamore J H. Use of Syntometrine in prevention of post-partum haemorrhage. Br Med J 1963; 1 : 1387-9.
4 Schwartz R H, Jones R W A. (1978) Transplacental hyponatraemia due to oxytocin. Br Med J 1978; 1 : 152-3.

5 Vere M F, Sellers S M. Letter: Transplacental hyponatraemia due to oxytocin. $\mathrm{Br}$ Med J 1978; $1: 362$.

6 McIntosh N, Walters R O. Effect of tolazoline in severe hyaline membrane disease. Arch Dis Child 1979; 54: 105-10.

7 Abbott T R, Rees G J, Dickinson D, Reynolds G, Lord D. Sodium nitroprusside in idiopathic respiratory distress syndrome. $\mathrm{Br}$ Med J 1978; 1 : 1113-4.

Correspondence to Dr M F Whitfield, Subregional Neonatal Intensive Care Unit, Jessop Hospital for Women, Leavygreave Road, Sheffield S3 7RE.

\title{
Prostaglandin synthetase inhibitor in an infant with congenital chloride diarrhoea
}

\author{
ADRIAN M B MINFORD AND DAVID G D BARR
}

Royal Hospital for Sick Children, Edinburgh

SUMMARY Hyper-reninaemia, hypokaluria, and hypokalaemia in an infant with congenital chloride diarrhoea improved during treatment with a prostaglandin synthetase inhibitor, ketoprofen. There was evidence of increased activity of the renin-aldosterone system when ketoprofen was stopped. It is suggested that prostaglandins may be involved in stimulating the renin-aldosterone system in congenital chloride diarrhoea.

In congenital chloride diarrhoea, juxtaglomerular hyperplasia, hyper-reninaemia, and hyperaldosteronism (with normal blood pressure), leading to hyperkaluria and hypokalaemia, complicate and worsen electrolyte imbalance and may predispose to vascular damage and further nephropathy. ${ }^{8}$ These features are also present in Bartter's syndrome in which increased renal production of prostaglandins has been implicated and a favourable response to prostaglandin synthetase inhibitors described. ${ }^{1-3}$ The clinical and biochemical effects of the prostaglandin synthetase inhibitor, ketoprofen, are reported in an infant with congenital chloride diarrhoea.

\section{Case report}

A Nigerian boy of $2.42 \mathrm{~kg}$ was born at 33 weeks' gestation by normal delivery after a pregnancy complicated by hydramnios. At 12 hours he developed watery diarrhoea and abdominal distension. He became dehydrated and hyponatraemic (serum Na $119 \mathrm{mmol} / \mathrm{l}, \mathrm{K} 4 \cdot 3 \mathrm{mmol} / \mathrm{l}$, urea $10 \cdot 3$ $\mathrm{mmol} / 1 ; 62 \mathrm{mg} / 100 \mathrm{ml}$ ). He was given intravenous fluids and the diarrhoea settled after 2 weeks. Stool electrolytes were not estimated. After discharge at 4 weeks, abdominal distension persisted although he was gaining weight and had no apparent diarrhoea. However, at 4 months his weight had fallen $<3$ rd centile and, as serum $\mathrm{K}$ was $2.3 \mathrm{mmol} / \mathrm{l}$, oral $\mathrm{KCl}$ was started.

Two weeks later he was admitted to this hospital with bronchiolitis which settled within 3 days. His weight of $4.49 \mathrm{~kg}$ was $<3 \mathrm{rd}$ centile and he was mildly dehydrated. Shortly after admission watery diarrhoea was noted and this persisted. Gross abdominal distension was present. Blood pressure was $90 / 60$ mmHg. Serum electrolytes on admission were: $\mathrm{Na} 132, \mathrm{~K} 2 \cdot 9, \mathrm{Cl} 83 \mathrm{mmol} / \mathrm{l}$, and urea $7.6 \mathrm{mmol} / \mathrm{l}$ $(45 \cdot 8 \mathrm{mg} / 100 \mathrm{ml})$. Chloride was undetectable in the urine. Urinary $\mathrm{Na}$ was $6 \mathrm{mmol} / \mathrm{l}$ and urinary $\mathrm{K}$ $46 \mathrm{mmol} / 1$. Stool electrolytes were: $\mathrm{Na} 51, \mathrm{~K} \mathrm{39}$, and $\mathrm{Cl} 103 \mathrm{mmol} / \mathrm{l}$. $\mathrm{Hb}$ was $10 \cdot 3 \mathrm{~g} / \mathrm{dl}$ and WBC $13.7 \times 10^{9} / 1$. Reducing substances were absent from the stools and no pathogens were isolated on stool culture. The plasma renin concentration (1261 $\mu \mathrm{U} / \mathrm{ml}$ ) was greatly raised compared with the normal adult range for this laboratory of $9-52 \mu \mathrm{U} / \mathrm{ml}$. Plasma aldosterone of $21 \mathrm{ng} / 100 \mathrm{ml}(0.58 \mathrm{nmol} / \mathrm{l})$ 